\title{
STUDIES ON THE BIOSYNTHESIS OF BASIC 16-MEMBERED MACROLIDE ANTIBIOTICS, PLATENOMYCINS. III \\ PRODUCTION, ISOLATION AND STRUCTURES OF PLATENOLIDES I AND II
}

\section{Tamotsu Furumai and Makoto Suzuki}

\author{
Microbial Chemistry Research Laboratory, Tanabe Seiyaku Co., Ltd., \\ Toda, Saitama, Japan
}

(Received for publication April 28, 1975)

\begin{abstract}
Two neutral macrocyclic lactones designated platenolides I and II have been isolated as the major products from the fermentation broth of the blocked mutants of Streptomyces platensis subsp. malvinus. These two compounds were isolated by solvent extraction and purified by column chromatography. Both platenolides [PL-I: $\mathrm{C}_{20} \mathrm{H}_{32} \mathrm{O}_{6}$, PL-II: $\mathrm{C}_{20} \mathrm{H}_{34} \mathrm{O}_{6}$ ] are closely related to the platenomycin aglycone.
\end{abstract}

In the previous paper of this series ${ }^{11}$ four glycosidic metabolites produced by the blocked mutants of Streptomyces platensis subsp. malvinus, group A, derived from the platenomycinproducing strain MCRL 0388 were described. The present report concerns the production, isolation and structure elucidation of two novel macrocyclic lactones produced by blocked mutants of $S$. platensis subsp. malvinus, group B. These compounds are named platenolides I (PL-I) and II (PL-II) and their structures are reported as shown in Fig. 1.

The biogenetic roles of PL-I and PL-II together with those of the metabolites produced by mutants of group A will be discussed Fig. 1. Structures of platenolides.

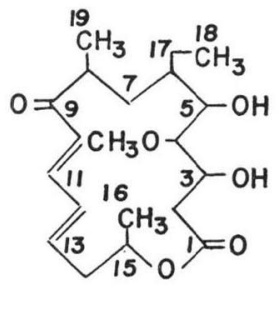

PL- I<smiles>C/C=C\C=C/CC(C)OC(=O)CC(O)C(O)C(O)C(C)CC(C)C(O)CC</smiles>

PL- II in a succeeding paper.

\section{Materials and Methods}

Organisms and media

The mutant strains (N-22 and U-92) used in this study were derived from Streptomyces platensis subsp. malvinus MCRL 0388 as described previously. ${ }^{21}$ These mutants are completely blocked mutants belonging to group B and produce substances PL-I and PL-II dealt with in this paper together with some minor compounds including 3-O-propionyl platenolides I (PPL-I) and II (PPL-II).

Media for maintenance of the strains, for seed culture (SC medium) and for production of metabolites (P medium) used in this study were the same as those described in the preceding papers. ${ }^{1,21}$

Production of platenolides

For the preparation of a vegetative inoculum, mature spores from a maintenance agar medium were inoculated into $500 \mathrm{ml}$, of Erlenmeyer flasks containing $100 \mathrm{ml}$ of SC medium and cultivated at $28^{\circ} \mathrm{C}$ for 2 days on a rotary shaker. Then, $150 \mathrm{ml}$ of vegetative inoculum were trans- 
ferred to 13 liters of $\mathrm{P}$ medium prepared in a 30-liter jar fermentor and submergedly cultured.

Assay of platenolides by thin-layer chromatography (TLC)

Five $\mathrm{ml}$ of the fermentation broth were extracted with $5 \mathrm{ml}$ of ethyl acetate. The extract was concentrated in vacuo and the dried residue was dissolved in $0.1 \mathrm{ml}$ of ethyl acetate for TLC analysis. Four $\mu 1$ of this solution were spoted on the TLC plate (adsorbent: silica gel kieserguhr $(6: 1)$ or silica gel sheets (Woelm)) and developed (solvent system: benzene - acetone, $7: 3)$. The amounts of PL-I and PL-II on a TLC plate were determined with a ultraviolet Spectrophotometer (Hitachi MPF-2A) at $232 \mathrm{~nm}$ or $280 \mathrm{~nm}$, comparing absorbancy with that of the respective standard sample.

\section{Results and Discussion}

Production of Platenolides

In shaken culture the strain U-92 was superior to $\mathrm{N}-22$ in productivity (productivity $(\mathrm{mcg} / \mathrm{ml})$ : PL-I $=62, \mathrm{PL}-\mathrm{II}=38$ by $\mathrm{N}-22$ and $\mathrm{PL}-\mathrm{I}=85$, PL-II $=65$ by $\mathrm{U}-92$ ), so that the strain U-92 was fermented in a 30-liter jar fermentor and in a 200-liter fermentor. The time course of PL-I and PL-II production are shown in Fig. 2. In a jar fermentor, with the temperature at $26 \sim 28^{\circ} \mathrm{C}$, PL-I appeared in the culture fluid at about 24 hours and reached a concentration maximum at about 48 hours and then decreased. PL-II appeared at about 40 hours and slowly continued to increase in concentration. In a 200 -liter fermentor at $23 \sim 25^{\circ} \mathrm{C}$, the production of both PL-I and PL-II gradually increased to a maximum. The temperature may affect the production.

\section{Isolation of Platenolides}

Platenolides were extracted from the filtered culture broth with an organic solvent and purified chromatographically through a silica gel column followed by a Sephadex LH-20

Fig. 2. A typical time course of platenolides production by the blocked mutant (strain U-92).

$\begin{array}{ll}\text { 30-liter jar fermentor } & 200 \text {-liter fermentor } \\ \text { Fermentation } & \\ \text { medium: } 13 \text { liters } & 120 \text { liters } \\ \text { Temperature: } 26 \sim 28^{\circ} \mathrm{C} & 23 \sim 25^{\circ} \mathrm{C} \\ \text { Aeration: } 7 \sim 8 \text { titers } / \mathrm{min} & 40 \sim 70 \text { liters } / \mathrm{min} . \\ \text { Agitation: } 250 \mathrm{r} . \mathrm{p} \cdot \mathrm{m} & 131 \mathrm{r} . \mathrm{p} \cdot \mathrm{m} . \\ \begin{array}{l}\text { Internal } \\ \text { pressure: } 0.5 \mathrm{~kg} / \mathrm{cm}^{2}\end{array} & 0.5 \mathrm{~kg} / \mathrm{cm}^{2}\end{array}$

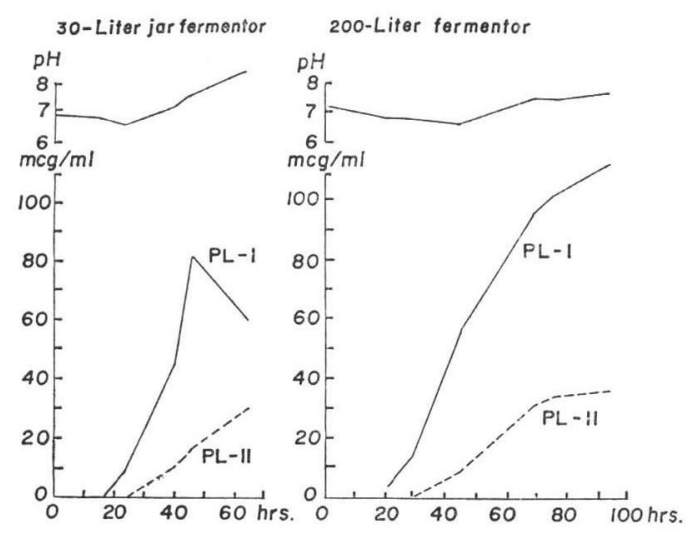
column as shown in Fig. 3. Thus, from 220 liters of the filtered broth, $12 \mathrm{~g}$ of PL-I and $4.6 \mathrm{~g}$ of PL-II were obtained which respectively gave a single spot on TLC.

Fig. 3. Isolation and purification of platenolides.

$$
\begin{aligned}
& \text { Filtered broth (220 liters) } \\
& \text { extraction with ethyl acetate }(70 \text { liters } \times 3) \\
& \text { Ethyl acetate layer } \\
& \text { | evaporation } \\
& \text { Syrup }(69 \mathrm{~g}) \\
& \mid \begin{array}{l}
\text { silica gel chromatography } \\
20 \sim 80 \% \text { ethyl acetate - benzene, stepwise }
\end{array} \\
& \text { PL-I PL-1 PL-II } \\
& \text { (Sephadex LH-20 chromatography, } \\
& \text { chloroform) }
\end{aligned}
$$

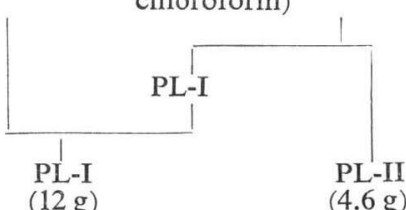


Table 1. Physicochemical properties of platenolides I and II.

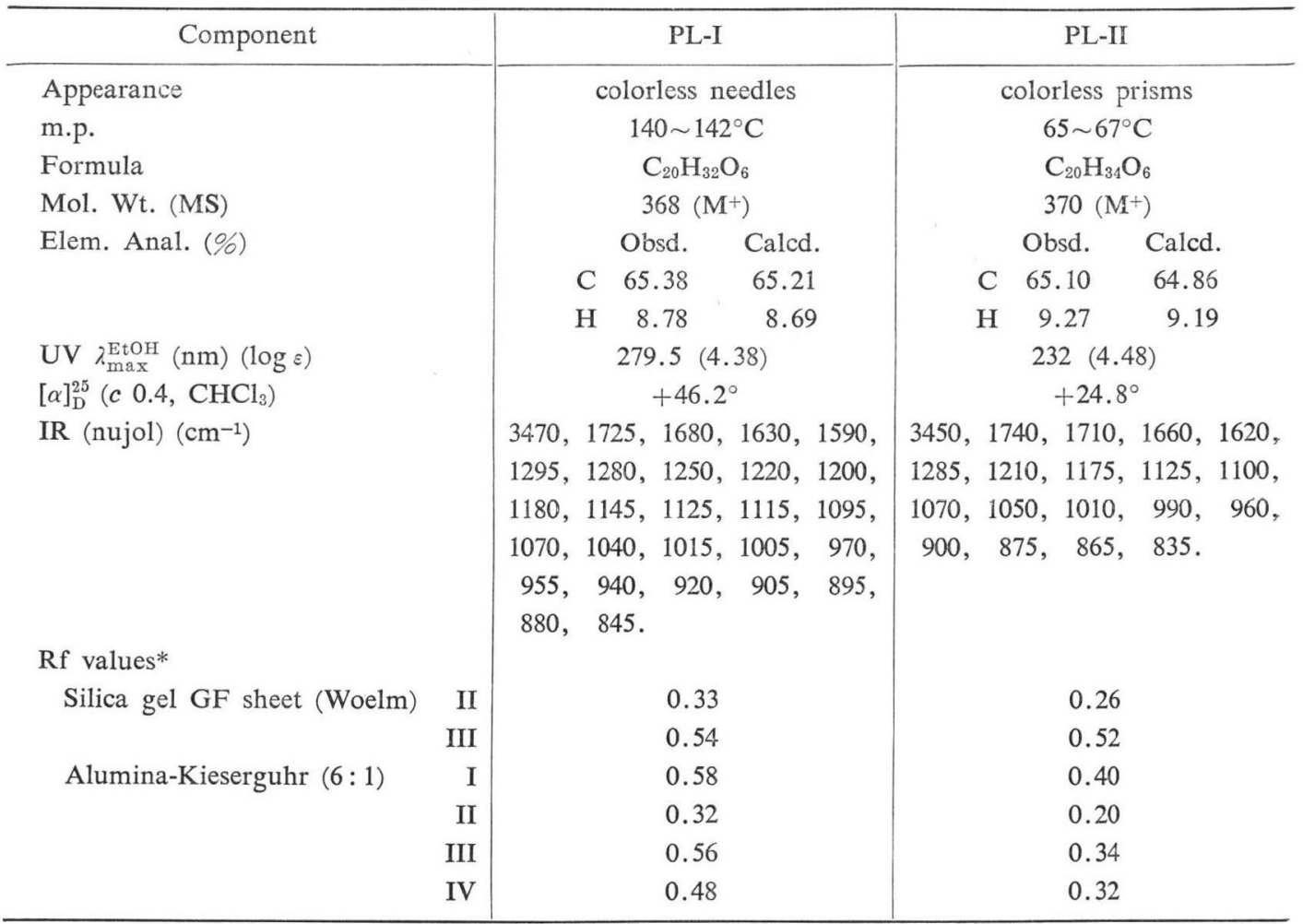

* Solvent system: I: Benzene-acetone $(1: 1)$, II: Benzene-acetone (7:3), III: Ethyl acetate acetone (8:2), IV: Benzene-acetone - water $(70: 29: 1)$.

Fig. 4. Mass spectra of acetyl platenolides.
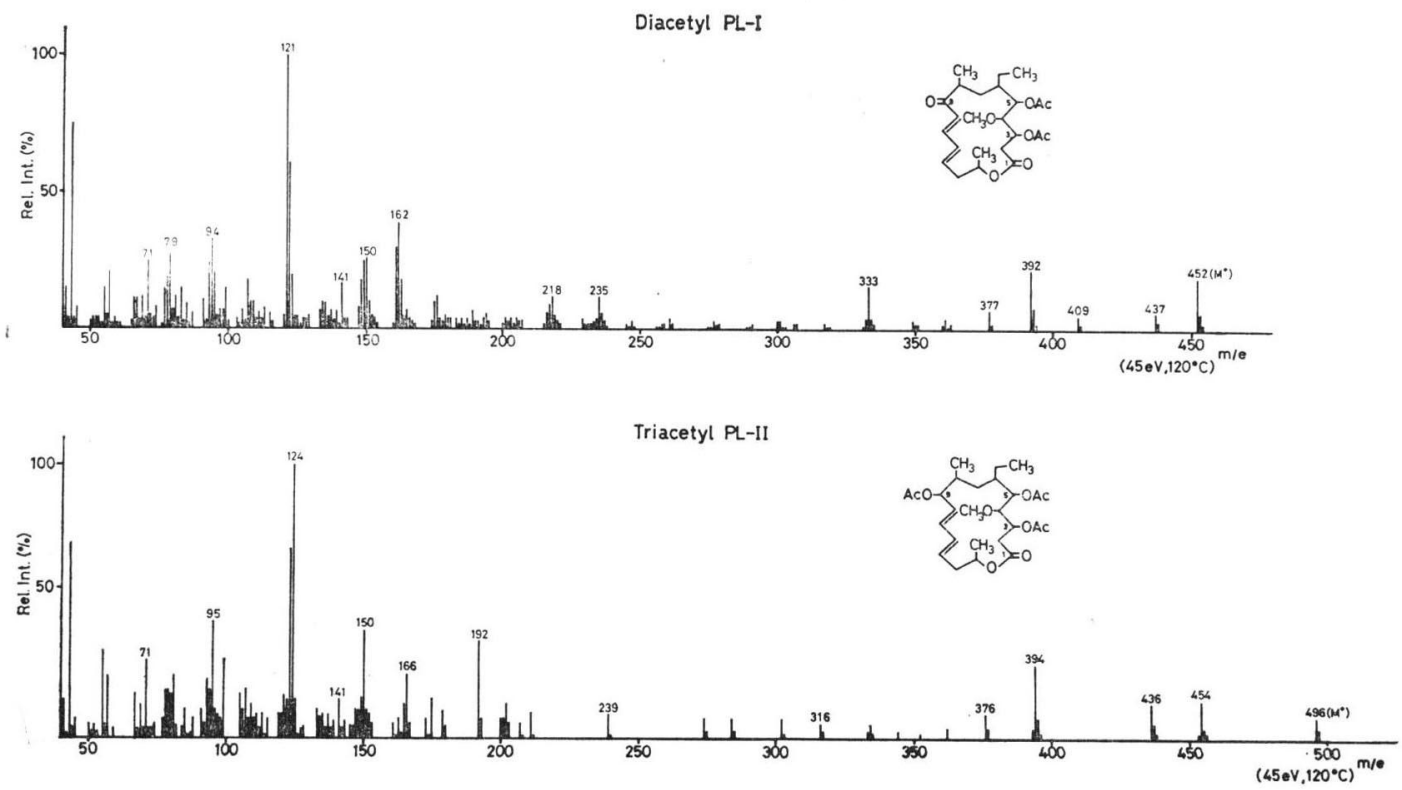
Physicochemical Properties and Structures of Platenolides

PL-I and PL-II obtained as above were recrystallized from benzene-cyclohexane as colorless crystals. The platenolides were visualized on a TLC plate as yellow (PL-I) or brown (PL-II) spots after spraying with $40 \%$ sulfuric acid followed by heating. Rf values and some physicochemical properties are shown as Table 1. PL-I and PL-II were neutral in nature and soluble in lower alcohols, lower alkyl acetates, chloroform, acetone and benzene, and almost insoluble in water, petroleum ether, $n$-hexane and cyclohexane. PL-I showed strong IR absorption bands at 3470 (hydroxyl), 1725 (lactone), 1680 (ketone), 1630 and $1590 \mathrm{~cm}^{-1}$ (double bond), while PL-II showed IR bands at 3450 (hydroxyl), 1740 1710 (lactone), 1660 and $1620 \mathrm{~cm}^{-1}$ (double bond). PL-I gave a diacetate and PL-II gave a triacetate derivatives with an usual acetylation procedure. Neither IR spectrum did showed the presence of a tertiary hydroxyl group. Mass spectra of the acetates are shown as Fig. 4. Abundant peaks were observed at $m / e 452\left(\mathrm{M}^{+}\right), 392\left(\mathrm{M}^{+}-\mathrm{CH}_{3} \mathrm{COOH}\right)$ and $333\left(\mathrm{M}^{+}-\mathrm{CH}_{3} \mathrm{COOH}-\mathrm{CH}_{3} \mathrm{COO} \cdot\right)$ with PL-I diacetate and at $m / e 496\left(\mathrm{M}^{+}\right), 436$ $\left(\mathrm{M}^{+}-\mathrm{CH}_{3} \mathrm{COOH}\right), \quad 376$ $\left(\mathrm{M}^{+}-2 \times \mathrm{CH}_{3} \mathrm{COOH}\right)$ and $316\left(\mathrm{M}^{+}-3 \times \mathrm{CH}_{3} \mathrm{COOH}\right)$ with PL-II triacetate. The ${ }^{1} \mathrm{H}-\mathrm{NMR}$ spectra of PL-I and PL-II measured in $\mathrm{CDCl}_{3}$ are shown as Fig. 5 . PL-I showed a triplet methyl signal $(\delta 0.90)$ at $\mathrm{C}-18$, two secondary methyl signals $(\delta 1.15 \sim 1.40)$ at $\mathrm{C}-16$, C-19, an O-methyl ( $\delta 3.58)$ signal, a doublet due to $\mathrm{H}-3(\delta 3.74, \quad \mathrm{~J}=10.5 \mathrm{~Hz})$, a doublet due to $\mathrm{H}-5$ $(\delta 4.05, \mathbf{J}=9.3 \mathrm{~Hz})$, a multiplet signal due to $\mathrm{H}-15$ at $\delta 5.24$, as well as three olefinic due to $\mathrm{H}-10, \mathrm{H}-12$, $\mathrm{H}-13 \quad(\delta 6.40 \sim 6.80)$ and an olefinic due to $\mathrm{H}-11$ $(\delta$ 7.25) protons. A proton due to H-11 in PL-I diacetate shifted to $\delta 7.32$ (multiplet), separating from the chloroform signal. Similarly, PL-II showed the following reso-

Fig. 5. ${ }^{1} \mathrm{H}-\mathrm{NMR}$ spectra of platenolides in $\mathrm{CDCl}_{3}$.
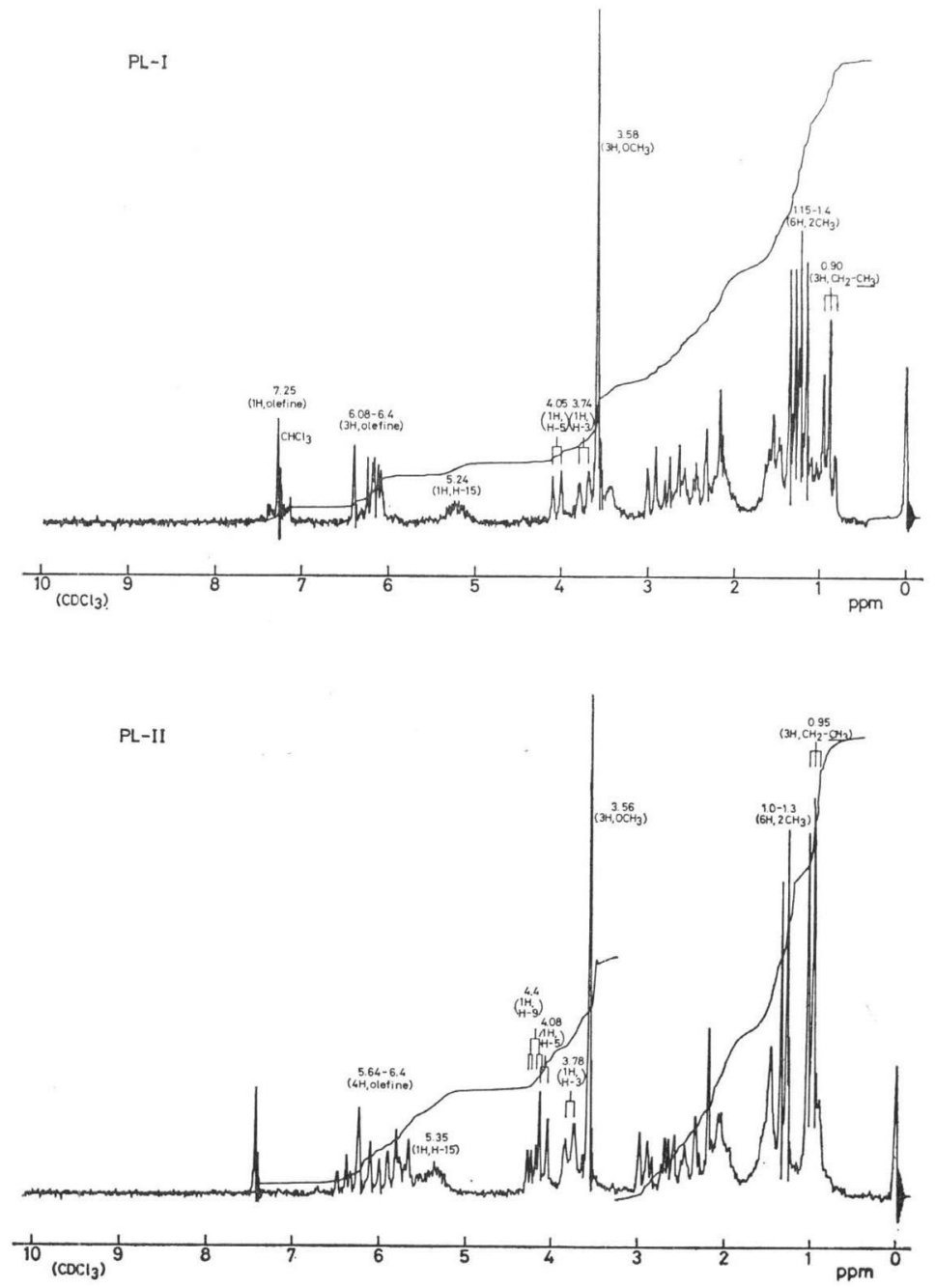
nances; a triplet at $\delta 0.95\left(-\mathrm{CH}_{2} \mathrm{CH}_{3}\right)$; a multiplet at $\delta 1.00 \sim 1.30\left(2 \times \mathrm{C}_{-} \mathrm{CH}_{3}\right)$; a singlet at $\delta 3.56$ $\left(-\mathrm{OCH}_{3}\right)$; a doublet at $\delta 3.78(\mathrm{H}-3, \mathrm{~J}=10.5 \mathrm{~Hz})$; a doublet at $\delta 4.08(\mathrm{H}-5, \mathrm{~J}=9.0 \mathrm{~Hz})$; a double doublet at $\delta 4.40(\mathrm{H}-9, J=9.6,4.5 \mathrm{~Hz})$; a multiplet at $\delta 5.35(1 \mathrm{H}, \mathrm{H}-15)$ and a multiplet at $\delta 5.64 \sim 6.50(4 \mathrm{H}$, olefinic).

The UV maximum at $279.5 \mathrm{~nm}$ in PL-I indicated the presence of an $\alpha, \beta, \gamma, \delta$-dienone chromophore as present in DDM-PLM ${ }^{1)}$ and PPL-I-MC ${ }^{1 \prime}$ and a maximum at $232 \mathrm{~nm}$ in PL-II indicated the presence of an $\alpha, \beta, \gamma, \delta$-diene alcohol chromophore as with DM-PLM ${ }^{11}$ and PPL-II-MC. ${ }^{\prime \prime}$ Further, the molecular formula suggested that PL-I is a 9-dehydro derivative of PL-II. This was supported by the IR spectrum of PL-I which exhibited a ketonic band $\left(1680 \mathrm{~cm}^{-1}\right)$ and also by the fact that PL-II was converted into PL-I by manganese dioxide oxidation.

The structure of PL-I was fully supported by a comparison of its NMR and mass spectra with those of DDM-PLM and PPL-I-MC. Instead of the aldehyde signal ( $\delta 9.55)$ observed in DDM-PLM, PL-I showed a triplet methyl signal at $\delta 0.90$ as in the case of PPL-IMC ( $\delta$ 0.74). Thus, similarly to PPL-I-MC, PL-I was concluded to have a methyl residue in place of an aldehyde function on the aglycone skelton of DDM-PLM. Moreover, PL-I did not show the presence of an $\mathrm{N}$-dimethyl signal due to mycaminose or a triplet methyl signal ascribed to a propionyloxy function. In the mass spectrum, diacetyl PL-I gave no fragment ions corresponding to diacetyl mycaminose as shown in diacetyl PPL-I-MC. In addition, the fragment ion at $m / e 333$ which was due to the loss of two acetyloxy functions in diacetyl PL-I was corresponding to the ion $\left(m / e 333\left(\mathrm{AGL}^{+}-\mathrm{C}_{2} \mathrm{H}_{5} \mathrm{COOH}\right)\right.$ ) of the aglycone in diacetyl PPL-I-MC. Based on the above findings, PL-I was defined as a compound which lacks both the mycaminose and propionyl functions of PPL-I-MC. Thus, the structures of PL-I and PLII were elucidated as depicted in Fig. 1.

\section{Experimental}

Isolation of platenolides

After 96 hours of cultivation of the strain U-92, the culture broth was adjusted to $\mathrm{pH} 6.0$ with $1 \mathrm{~N} \mathrm{HCl}$ and filtered with Celite-545 $(1.2 \mathrm{~kg})$. The filtered broth $(220$ liters $)$ was extracted with ethyl acetate $(70$ liters $\times 3)$. The extract was concentrated in vacuo and the resulting syrup $(69 \mathrm{~g})$ triturated with benzene $(200 \mathrm{ml})$, the insoluble material removed by filtration, and the extract roughly fractionated into components by column chromatography on silica gel $(1 \mathrm{~kg})$ prepared in benzene. Fractions eluted with benzene containing $20 \sim 80 \%$ ethyl acetate were monitered by TLC. Crude PL-I and PL-II thus obtained were further purified using Sephadex LH-20 columns prepared in chloroform. Eluted fractions giving a single spot of PL-I or PL-II on TLC were combined and evaporated. The resultant PL-I $(12.0 \mathrm{~g})$ or PL-II $(4.6 \mathrm{~g})$ was recrystallized from benzene-cyclohexane. Thus, pure PL-I (10.9 g) and PL-II ( $4.3 \mathrm{~g})$ were obtained respectively as colorless crystals.

From the fermentation broth (8 liters) obtained by cultivating another mutant strain (N-22) for 5 days under shaking - the procedures were the same as those applied to the strain U-92$250 \mathrm{mg}$ of PL-I and $175 \mathrm{mg}$ of PL-II were obtained respectively as colorless crystals. IR, UV and mass spectra of these products showed a good agreement with those produced by the strain U-92.

Oxidation of platenolide II with manganese dioxide

PL-II $(50 \mathrm{mg}$ ) was oxidized in $3 \mathrm{ml}$ of acetone with $500 \mathrm{mg}$ active manganese dioxide by 3 hours stirring at room temperature. After removing the oxidant, the solvent was evaporated, and the residue was chromatographed over Sephadex LH-20 with chloroform. The fractions 
containing the desired product were combined and concentrated to dryness. Recrystallization from benzene-cyclohexane gave colorless needles $(31.4 \mathrm{mg}), \mathrm{m} . \mathrm{p} .140 \sim 142^{\circ} \mathrm{C}$. This product was identified with PL-I by mixed m.p., UV, MS and TLC.

Diacetyl platenolide I

PL-I (200 mg) was dissolved in $2 \mathrm{ml}$ of dry pyridine, and $2 \mathrm{ml}$ of acetic anhydride was added. The reaction mixture was kept at room temperature overnight and then poured onto cracked ice. The solution was extracted with ethyl acetate $(30 \mathrm{ml} \times 2)$. The extract was washed with water $(30 \mathrm{ml})$ and dried over anhydrous sodium sulfate, and then evaporated. Recrystallization of the residue from benzene - $n$-hexane gave colorless needles of diacetyl PL-I (120 mg). m.p.: $180 \sim 181^{\circ} \mathrm{C}$. Anal. Calcd. for $\mathrm{C}_{24} \mathrm{H}_{36} \mathrm{O}_{8}$ : C 63.70, H 8.02. Found: C $63.78, \mathrm{H} 8.01$. MW: $452\left(\mathrm{M}^{+}, m / e\right)$. UV $(\mathrm{EtOH}): 279.5 \mathrm{~nm}(\log \varepsilon 4.40)$. IR (nujol): 1755, 1685, 1635, 1600, 1315,1240 and $1190 \mathrm{~cm}^{-1}$. ${ }^{1} \mathrm{H}-\mathrm{NMR}\left(\mathrm{CDCl}_{3}\right): \delta 2.05\left(3 \mathrm{H}, \mathrm{s}, \mathrm{CH}_{3} \mathrm{CO}-\right), \delta 2.08\left(3 \mathrm{H}, \mathrm{s}, \mathrm{CH}_{3} \mathrm{CO}-\right)$.

Triacetyl platenolide II

PL-II $(250 \mathrm{mg})$ was dissolved in $3 \mathrm{ml}$ of dry pyridine, and $3 \mathrm{ml}$ of acetic anhydride was added. Work-up as above gave a yellow oil $(290 \mathrm{mg}$ ) and addition of $n$-hexane afforded crystalline material. Recrystallization from benzene- $n$-hexane gave colorless needless of triacetyl PL-II (156 mg). m.p.: $157 \sim 158^{\circ} \mathrm{C}$. Anal. Calcd. for $\mathrm{C}_{26} \mathrm{H}_{40} \mathrm{O}_{9}:$ C 62.90, H 8.06. Found: C 62.97, $\mathrm{H}$ 8.05. MW: $496\left(\mathrm{M}^{+}, m / e\right)$. UV (EtOH): $232 \mathrm{~nm}(\log \varepsilon 4.48)$. IR (nujol): 1745, 1730, 1660, $1620,1305,1245,1230$ and $1180 \mathrm{~cm}^{-1}$. ${ }^{1} \mathrm{H}-\mathrm{NMR}\left(\mathrm{CDCl}_{3}\right): \delta 2.05\left(3 \mathrm{H}, \mathrm{s}, \mathrm{CH}_{3} \mathrm{CO}-\right), \delta 2.12$ $\left(3 \mathrm{H}, \mathrm{s}, \mathrm{CH}_{3} \mathrm{CO}-\right), \delta 2.15$ ( $3 \mathrm{H}, \mathrm{s}, \mathrm{CH}_{3} \mathrm{CO}-$ ).

\section{Acknowledgement}

Throughout the parts II and III of this series, the authors wish to thank Dr. T. OKUDA, manager of this laboratory, for his interest and encouragement, and Dr. K. KOTERA and his collaborators of Analytical Center of this company for the instrumental and elemental analyses. They also express their thanks to Dr. A. Kinumaki, Mr. Takeda and Mr. Y. Seki of this laboratory for their help.

\section{References}

1) Furumai, T. \& M. Suzuki: Studies on the biosynthesis of basic 16 -membered macrolide antibiotics, platenomycins. II. Production, isolation and structures of 3-O-propionyl-5-O-mycaminosyl platenolides I and II, 9-dehydro demycarosyl platenomycin and demycarosyl platenomycin. J. Antibiotics 28: 775 782, 1975

2) Furumai, T. \& M. Suzuki: Studies on the biosynthesis of basic $16-$ membered macrolide antibiotics, platenomycins. I. Selection of and cosynthesis by non-platenomycin-producing mutants. J. Antibiotics 28: $770 \sim 774,1975$ 